\title{
Evaluation of crisphead lettuce cultivars in different cover types by manova and discriminant analysis
}

\author{
Izabela Regina C de Oliveira ${ }^{1}$; Marcelo T Rezende ${ }^{2}$; Carlos Tadeu dos S Dias ${ }^{1}$; Daniela de S Gomes ${ }^{2}$; \\ Élberis P Botrel' ${ }^{2}$, Luiz Antônio A Gomes ${ }^{2}$ \\ 'USP-ESALQ, C. Postal 09, 13418-900 Piracicaba-SP; izabela.rco@gmail.com (autor para correspondência); ctsdias@usp.br; ${ }^{2}$ UFLA, C. \\ Postal 3037,37200-000 Lavras-MG; tmarcelo84@gmail.com; dani_gomes@hotmail.com; elberis@dag.ufla.br; laagomes@dag.ufla.br
}

\begin{abstract}
In many agricultural experiments the variables are biologically correlated and it is inappropriate to study them only under univariate analysis. Therefore, we evaluated commercial characteristics of crisphead lettuce cultivars and covers under a multivariate approach, using canonical discriminant analysis. We used a split plot design and we tested the cover crop, cultivar and interaction effects by using MANOVA $(\alpha=5 \%)$. Means and its standard errors were obtained for average total weight, weight of the head, volume and density of plants. Canonical discriminant analyses were performed using PROC CANDISC procedure in SAS (SAS Institute, 2008) system. Canonical plots were obtained using JMP 9.0 (SAS Institute, 2010) linked to SAS database. With these plots it was possible to note the differences among factors levels. When polyethylene film was used as cover the plants had inferior commercial characteristics than plants in which cover crops were used. Thus, the cover with polyethylene film can be discouraged in the cultivation of crisphead lettuce, promoting environmental sustainability. We suggest these multivariate techniques in horticulture studies.
\end{abstract}

Keywords: Lactuca sativa, cover crop, multivariate analysis, organic production.

\section{RESUMO}

Avaliação de cultivares de alface americana em diferentes coberturas por manova e análise discriminante

Em muitos experimentos agrícolas as variáveis respostas são biologicamente correlacionadas e torna-se inadequado analisá-las apenas sob a ótica univariada. Dessa forma, características comerciais de diferentes cultivares de alface americana e diferentes coberturas foram analisadas por uma abordagem multivariada, utilizando a técnica de análise discriminante canônica. $\mathrm{O}$ experimento foi realizado em esquema de parcelas subdividas e foram realizados testes de hipóteses para efeitos de cobertura, cultivar e interação entre os fatores, utilizando MANOVA $(\alpha=5 \%)$. As médias e respectivos erros padrão foram obtidos para peso médio total, peso médio da cabeça, volume e densidade média das plantas. Análises discriminantes canônicas foram implementadas pelo comando PROC CANDISC do sistema computacional SAS 9.2 (SAS Institute, 2008) para os dois fatores. Figuras relacionando às duas primeiras variáveis canônicas foram obtidas usando o sistema computacional JMP 9.0 (SAS Institute, 2010) associado à base de dados do SAS. Esse procedimento possibilitou uma fácil visualização do comportamento dos fatores em estudo. $\mathrm{O}$ uso do plástico resultou em plantas com características comerciais inferiores se comparadas às resultantes de coberturas vegetais. Dessa forma, seu uso pode ser desencorajado no cultivo da alface do tipo americana, favorecendo a conservação ambiental. Recomenda-se o uso dessas técnicas multivariadas em estudos de olericultura.

Palavras-chave: Lactuca sativa, cobertura vegetal, análise multivariada, produção orgânica.

(Recebido para publicação em 9 de julho de 2012; aceito em 10 de junho de 2013) (Received on July 9, 2012; accepted on June 10, 2013)

L ettuce, frequently consumed with tomato, is the favorite vegetable for salads, for its pleasant and refreshing flavor, besides being easy to prepare. It is also an important source of vitamins and minerals, such as vitamin $\mathrm{A}$ and calcium (Ceasa, 2012). Nowadays most of the lettuce cultivated in the Country is originated from the conventional system, which means, with the use of chemical fertilizers and mulching. This material brings advantages such as better growth of the plants and marketable productivity, which are consequences of lower air and soil temperature, lower evapotranspiration, greater aeration and less soil compaction (Efferson, 1985; Costa Araújo, 1993).

Despite the efficiency of conventional cultivation, the use of mulching can cause negative impacts on the environment. Moreover, in the latest years the demand for organic products has been increasing, because besides providing greater environmental conservation, these products are healthier and they have greater biological value (Khatounian, 2001). Several studies on the production of organic food have been carried out, but it is still interesting the development of new sustainable technologies adapted to our climate and soil conditions (Roel, 2002).

The use of cover crops can be an alternative to mulching because they are able to modify the population of spontaneous plants (weeds) due to allelopathic effects and competition for water, light and nutrients (Favero 
et al., 2001). Green manure also brings benefits, such as the increase of organic matter content, greater availability of nutrients, greater effective cation exchange capacity, the decrease in aluminum levels and recyclability and mobilization of nutrients (Calegari et al., 1993).

The effect of using different covers can be evaluated on various characteristics of a crop through the implementation and analysis of experiments. Andrade Júnior et al. (2005) studied the use of cover crops as an alternative to polyethylene film in the growing of looseleaf lettuce and concluded that coffee husk cover provided best development of lettuce. The authors used univariate analyses of variance to study the variable responses of interest. However, in many agricultural experiments these characteristics or responses of interest are biologically correlated and it is inappropriate to evaluate them only under univariate approach.

Besides necessary in many cases, multivariate tools provide a simultaneous view of all the variables involved in the phenomenon of interest, which it is not possible using univariate methods. Several multivariate methods are available and the choice of the best tool to be used in a set of experimental data depends on the types of variables involved in the study and on the goals of the researcher. Lots of these methods such as the multivariate analysis of variance (MANOVA), multivariate regression, factor analysis, cluster analysis, discriminant and principal components are well described in Johnson \& Wichern (2007).

According to Johnson \& Wichern (2007), the discriminant analysis as a separative procedure aims to investigate the differences observed when the casual relationships are not well defined. In this kind of analysis, linear combinations of the original variables responses are obtained in a way to provide the maximum possible discrimination among treatments, through $\mathrm{F}$ test. These functions are usually called canonical variables. Rosário et al. (2008) highlight the difference between this method and MANOVA, which goal is testing the equality of vectors of multivariate population means for different treatments. These authors used these two methods to evaluate the performance of broiler chickens.

Many researches, in different areas of knowledge, have been carried out using the canonical discriminant analysis. Desuó et al. (2011) studied morphological differences in wasps in different colonies and used the JMP system associated with the SAS database to obtain confidence ellipses of the treatment means based on the first two canonical variables. Specifically in horticulture studies, some researches on tolerance of sweet pepper are highlighted (Ariyo et al., 2011) and weed suppression in organic peppers using different covers (Isik et al., 2009). In this latest work PROC CANDISC procedure is used as a tool for discriminant analysis.

In this study, some commercial characteristics of crisphead lettuce grown in different covers are investigated under a multivariate approach using MANOVA and discriminant analysis. The latter was used in order to reduce the number of original variables and discriminate the different treatments. A contribution of this paper is in widespread the use of these multivariate tools for the statistical analyses of the experiments. For this reason, the SAS program codes are provided in this paper.

\section{MATERIAL AND METHODS}

The experiment - The data used in this work is related to an experiment carried out in Lavras, Minas Gerais state, Brazil, in Rhodic Hapludox Oxisol. The aim was to study the use of the cover crops (mulch) as an alternative to polyethylene film in the production of different crisphead lettuce cultivars. The experiment was carried out in a split plot design. The cover factor was randomized in blocks in the plots, with three replications, and the cultivar factor was completely randomized in subplots.

For the cover factor, five kinds of cover crop were evaluated (sunn hemp, 50 plants $/ \mathrm{m}^{2}$, jack bean, 10 plants/ $\mathrm{m}^{2}$, millet, 200 plants $/ \mathrm{m}^{2}$, turnip, 120 plants $/ \mathrm{m}^{2}$ ) and black polyethylene film. For the cultivar factor, three existing commercial materials were studied (Rubete, Laurel and Raider Plus), defining a $5 \times 3$ factorial.

For the cover planting, performed on January 25, 2010, the soil was plowed, harrowed and furrowed, sowing being done in rows. Each plot was 6 meters long and 2 meters wide. The green manure was cut on the own plot on April 26,2010 . Then, the subdivision of the plots was performed, where three head lettuce cultivars were transplanted on each cover.

The head lettuce is produced on a large scale to be processed on fastfood chains, for example. In order to be commercialized, the plants must have commercial characteristics within some standards established by the buyer. Volume, weight and density are some of the characteristics used to establish the standards for commercialization.

Thus, the variables observed in this study were average total weight, average weight of the head, average volume and average density, considering six plants in each experimental unit.

Statistical Analyses - The treatments of the experiment consist in all the combinations among three lettuce cultivars (Laurel, Raider Plus and Rubete) and five types of cover (sunn hemp, jack bean, millet, turnip and polyethylene film), total of fifteen treatments.

The statistical model used in the multivariate analysis was:

$$
\boldsymbol{y}_{i j k}=\boldsymbol{\mu}+\boldsymbol{B l}_{k}+\boldsymbol{\alpha}_{i}+\boldsymbol{B l} \times \boldsymbol{\alpha}_{(k i)}+\boldsymbol{\beta}_{j}+
$$

$\gamma_{(i j)}+\varepsilon_{i j k}$

where $i=1,2, \ldots, 5 ; j=k=1,2,3 ; \boldsymbol{y}_{i j k}$ is the multivariate vector of observations for $i$-th cover, $j$-th cultivar and in $k$-th block; $\boldsymbol{\mu}$ is the general multivariate vector of constants inherent for all the observations; $\boldsymbol{B l}_{k}$ is the multivariate vector of effects of the $k$-th block; $\boldsymbol{\alpha}_{i}$ is the multivariate vector of effects of the $i$-th cover; $\boldsymbol{B} \boldsymbol{l} \times \boldsymbol{\alpha}_{(k i)}$ is the multivariate vector of interaction effects between $k$-th block and $i$-th cover, that means, error of the plot; $\boldsymbol{\beta}_{j}$ is the multivariate vector of effects of $j$-th cultivar; $\gamma_{(i j)}$ is the 
multivariate vector of interaction effects between $i$-th cover and $j$-th cultivar; $\boldsymbol{\varepsilon}_{i j k}$ is the multivariate vector of errors associated to observations $\boldsymbol{y}_{i j k}$.

The vector of errors follows a multivariate normal distribution

$$
\left(\varepsilon_{i j k} \sim N_{4}(\mathbf{0}, \Sigma)\right)
$$

and the vectors corresponding to the different experimental units are independently distributed.

All the statistical analyses were performed in SAS 9.2 (2008) for Windows. To verify the differences among cultivars and covers, considering the model showed in (1), the multivariate analysis of variance, implemented by PROC GLM, was used. The null hypothesis for equality of vectors of effects of cover, effects of cultivar and of interaction in relation to the four commercial characteristics observed are given, respectively, by

$H_{0}:\left[\begin{array}{l}\alpha_{11} \\ \alpha_{12} \\ \alpha_{13} \\ \alpha_{14}\end{array}\right]=\left[\begin{array}{l}\alpha_{21} \\ \alpha_{22} \\ \alpha_{23} \\ \alpha_{24}\end{array}\right]=\cdots=\left[\begin{array}{l}\alpha_{51} \\ \alpha_{52} \\ \alpha_{53} \\ \alpha_{54}\end{array}\right]$,

$H_{0}:\left[\begin{array}{l}\beta_{11} \\ \beta_{12} \\ \beta_{13} \\ \beta_{14}\end{array}\right]=\left[\begin{array}{l}\beta_{21} \\ \beta_{22} \\ \beta_{23} \\ \beta_{24}\end{array}\right]=\left[\begin{array}{l}\beta_{31} \\ \beta_{32} \\ \beta_{33} \\ \beta_{34}\end{array}\right]$

$H_{0}:\left[\begin{array}{l}\gamma_{11} \\ \gamma_{12} \\ \gamma_{13} \\ \gamma_{14}\end{array}\right]=\left[\begin{array}{l}\gamma_{21} \\ \gamma_{22} \\ \gamma_{23} \\ \gamma_{24}\end{array}\right]=\cdots=\left[\begin{array}{l}\gamma_{15} 1 \\ \gamma_{15} 2 \\ \gamma_{15} 3 \\ \gamma_{15} 4\end{array}\right]$

All hypotheses were tested against the alternative hypothesis $\left(H_{1}\right)$ in which, at least, one different effect among these vectors can be observed.

The program code for obtaining the MANOVA is presented below. In this program var represents cultivars, cob represents covers and bloco represents the blocks. The variables weightT, weightC, volume and density refer to response variables total weight, weight of the head, average volume and density of the plants.

proc glm;

class var cob bloco;

model weightT weightC volume density

$=$ bloco cob bloco*cob var cob*var;

test $\mathrm{h}=\mathrm{cob} \mathrm{e}=$ bloco $*$ cob;

contrast 'Laurel vs Raider Plus' var
1 - 10 ;

contrast 'Laurel vs Rubete' var 10 -1; contrast 'RPlus vs Rubete' var 0 1-1; contrast 'Sunn hemp vs Beans'

cob $1-1000$;

contrast 'Sunn hemp vs Millet'

cob 10 -1 0 0;

contrast 'Sunn hemp vs Turnip'

cob 100 - 10 ;

contrast 'Sunn Hemp vs Polyethylene

film`cob $10000-1$;

contrast 'Beans vs Millet'

cob $01-100$;

contrast 'Beans vs Turnip'

cob 010 -1 0 ;

contrast 'Beans vs Polyethylene film' cob 0100 - 1 ;

contrast 'Millet vs Turnip'

cob $001-10$;

contrast 'Millet vs Polyethylene film' cob 0010 - 0 ;

contrast 'Turnip vs Polyethylene film ' cob $00001-1$;

manova $\mathrm{h}=\mathrm{cob}^{*}$ var /printE printH canonical; /*MANOVA for interaction cob*var*/

/*MANOVA for main effects */ manova $\mathrm{h}=\mathrm{var} / \mathrm{print} \mathrm{E}$ printH canonical; manova $\mathrm{h}=\mathrm{cob} /$ printE printH canonical; run;

Initially, the interaction model between cultivar and cover factors was tested and, in the same step, all the multivariate contrasts between the levels of each factor were obtained. When no significant interaction was noticed $(\alpha=5 \%)$, then the multivariate analyses of variance of the main effects were performed.

The canonical discriminant analyses were implemented by PROC CANDISC in SAS (SAS Institute, 2008). Standardized canonical coefficients were obtained through the total sample and the total variance explained by each canonical variable. This step allows the view of the differences among the three cultivars and among the five covers when providing a set of canonical variables, the linear combination of the original variables, which provide the best discrimination between groups maximizing the variance between groups related to the variance within the groups.

The codes of the discriminant analyses for the cultivar and cover factors are presented.

/* Discriminant Analysis for cultivars $* /$

proc candisc all out=DISC;

class var;

var weight T weightC volume density;

run;

proc print data $=$ DISC;

title 'scores';

run;

/* Discriminant analysis for covers */ proc candisc all out=DISC2;

class cob;

Var weight $\mathrm{T}$ weightC volume density; run;

proc print data $=$ DISC2;

title 'scores 2';

run;

Figures were used to represent the two canonical variables (Can 1 and Can2), considering the cultivar factor and the cover factor, and on them were presented ellipses with $95 \%$ confidence for the mean vectors for each factor level. For these analyses JMP 9.0 (SAS Institute, 2010) linked to database (DISC and DISC2) of SAS program was used.

\section{RESULTS AND DISCUSSION}

The residual correlations between the response variables of interest were calculated and the results found justify the use of the multivariate analysis methods in detriment of the univariate one. The variable total weight was related to the variable weight of the head $(r=0.94)$ and density $(r=0.54)$. The variable density was related to the weight of the head ( $r=0.64)$ and volume $(r=-0.48)$. Lower correlations were found between volume and total weight $(r=0.27)$ and between volume and the weight of the head $(r=0.14)$.

According to the results obtained by MANOVA, the interaction between the cultivar and cover factors was not significant (Lambda de Wilks $=0.1492$ and $\operatorname{Pr}>F=0.1491)$. That means that 
Table 1. Pairwise squared Mahalanobis' distances* and probability values for the multivariate contrasts**, considering the cultivar factor (distâncias quadráticas de Mahalanobis*e valores descritivos de probabilidade ${ }^{* *}$ pelo teste $\mathrm{F}$ para os contrastes multivariados, considerando o fator cultivar). Lavras, UFLA, 2010.

\begin{tabular}{lccc}
\hline Cultivars & Laurel & Raider Plus & Rubete \\
\hline Laurel & 0 & 3.4365 & 4.8183 \\
Raider Plus & 0.0004 & 0 & 0.3786 \\
Rubete & $<0.0001$ & 0.3864 & 0
\end{tabular}

*The squared Mahalanobis' distances are above the diagonal line (as distâncias quadráticas de Mahalanobis estão acima da linha diagonal). **The probability values for the contrasts by the F-test are below the diagonal line (os valores de probabilidade dos contrastes pelo teste F estão abaixo da linha diagonal).

Table 2. Pairwise squared Mahalanobis distances* and probability values** for the multivariate contrasts, considering the cover factor (distâncias quadráticas de Mahalanobis* e valores descritivos de probabilidade ${ }^{* *}$ pelo teste $\mathrm{F}$ para os contrastes multivariados, considerando o fator cobertura). Lavras, UFLA, 2010.

\begin{tabular}{lccccc}
\hline Cover crop & Sunn hemp & Jack bean & Millet & Turnip & $\begin{array}{c}\text { Polyethylene } \\
\text { film }\end{array}$ \\
\hline Sunn hemp & 0 & 3.7978 & 2.7606 & 1.1715 & 3.8648 \\
Jack bean & $<0.0001$ & 0 & 0.2698 & 2.9196 & 1.8264 \\
Millet & 0.0004 & 0.6684 & 0 & 1.8664 & 0.9205 \\
Turnip & 0.1411 & 0.0001 & 0.0016 & 0 & 1.7075 \\
$\begin{array}{l}\text { Polyethylene } \\
\text { film }\end{array}$ & $<0.0001$ & 0.0284 & 0.1452 & 0.0021 & 0 \\
\hline
\end{tabular}

*The squared Mahalanobis' distances are above the diagonal line (as distâncias quadráticas de Mahalanobis estão acima da linha diagonal). **The probability values for the contrasts by the F-test are below the diagonal line (os valores de probabilidade dos contrastes pelo teste F estão abaixo da linha diagonal).

the behavior of the cultivars was the same, independently the type of cover used, considering all the variables simultaneously. The main effect of each factor was, then, investigated separately.

Mahalanobis quadratic distances and the probabilities of significant effects, by $\mathrm{F}$ test $(p<0.05)$, of the multivariate contrasts for both factors are shown in Tables 1 and 2. For the cultivar factor, significant differences were noticed between Laurel and jack beans, sunn hemp and millet, sunn hemp and polyethylene film, jack beans and turnip, jack beans and polyethylene film, millet and turnip, turnip and polyethylene film differed statistically among them.

Table 3 shows canonical coefficients standardized by the total sample and the percentage of the total variability explained by each canonical variable, considering the factors in this study. Only two discriminant functions were obtained for cultivar factor, the first one being responsible for $95.58 \%$ of the variation of data and the second $4.42 \%$. That means that, from four original response variables, only one canonical variable (Can1) was necessary to explain $95.58 \%$ of the total variation. According to Rosário et al. (2008), the reduction in the number of variables makes it easy to evaluate the performance of the individuals or treatments, since it is often difficult to consider properly each response variable in one general index. Also, in this study, each response variable was considered according to the contribution for each canonical variable, which has as a principle to separate, as much as possible, the levels of the factor.

Considering the first canonical variable for the cultivar factor $(\mathrm{Can} 1=$ $-4.44 P T+2.82 P C+1.77 V+0.38 D)$ where PT is total weight, $\mathrm{PC}$ is weight of the head, D is density and V is volume, high coefficient for the variable weight of the head and a little lower coefficient for volume were noticed, all the variables being in contrast to the total weight variable, which showed high negative coefficient in the discriminant function. Considering the second canonical variable for this same factor $(\mathrm{Can} 2=-0.72 P T-1.31 P C$

Table 3. Total-sample standardized canonical coefficients and total variation explained by each canonical variable (Can), considering the cultivar and cover factors (coeficientes canônicos padronizados pelo total amostral e porcentagem da variação total explicada por cada variável canônica, considerando os fatores cultivar e cobertura). Lavras, UFLA, 2010.

\begin{tabular}{lcccccc}
\hline Commercial characteristics & Can1* & Can2* & Can 1 & Can 2 & Can 3 & Can 4 \\
\hline Total weight & -4.44 & -0.72 & -0.65 & -3.66 & 0.48 & -0.51 \\
Weight of the head & 2.82 & -1.31 & 1.23 & 2.30 & -3.64 & 0.98 \\
Volume & 1.77 & 1.52 & 0.56 & 0.99 & 3.09 & -1.10 \\
Density & 0.38 & 1.73 & 0.33 & 0.61 & 1.57 & -1.08 \\
\hline CV $(\%)$ & 95.58 & 4.42 & 66.03 & 27.66 & 5.79 & 0.52 \\
\hline
\end{tabular}

* Canonical coefficients considering the cultivar factor (coeficientes canônicos para o fator cultivar). 


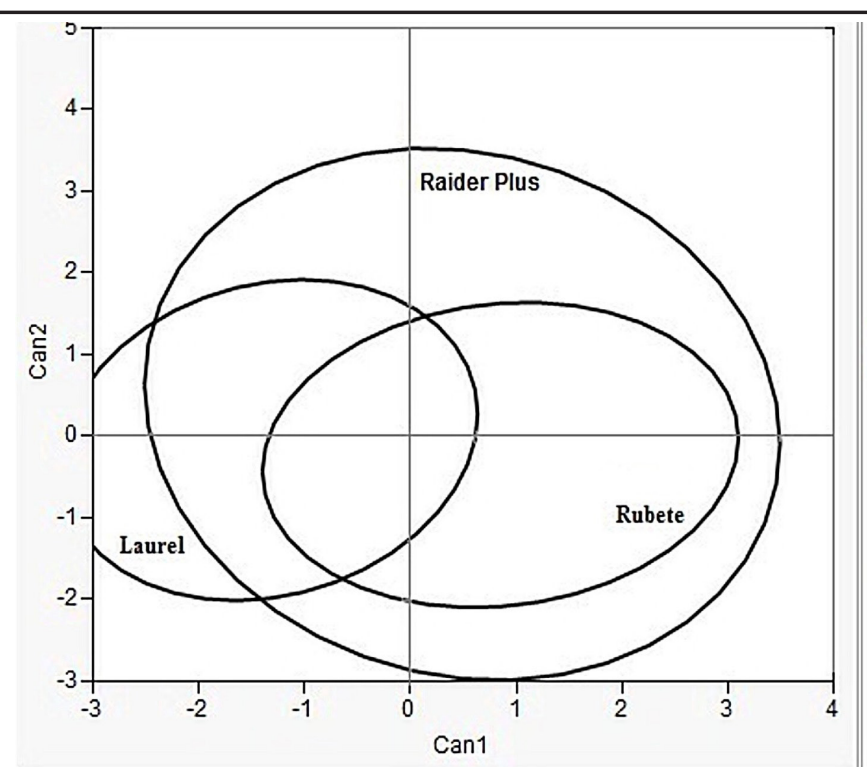

(a)

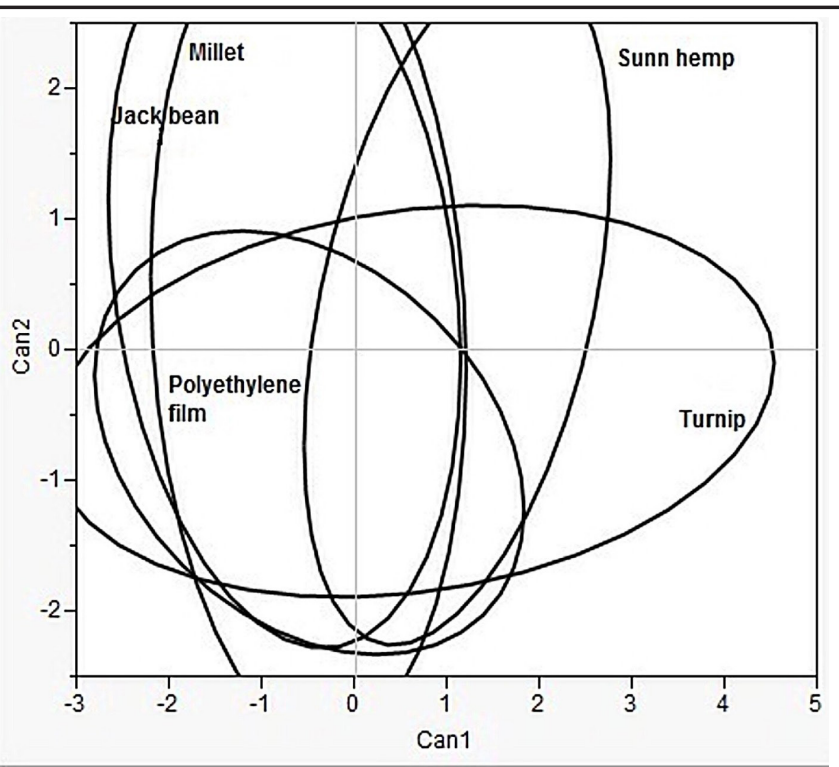

(b)

Figure 1. The 95\% confidence ellipses of the mean vectors of cultivar levels (a) and cover levels (b), according to the first and second canonical variables (Can1 and Can2) [elipses de 95\% de confiança dos vetores de médias para os níveis dos fatores cultivar (a) e cobertura (b), de acordo com a primeira e segunda variáveis canônicas (Can1 e Can2)]. Lavras, UFLA, 2010.

$+1.52 \mathrm{~V}+1.73 \mathrm{D})$, the variables with higher coefficients in function are density and volume. Moreover, it is possible to extract a contrast between volume and density variable in relation to the weight of the head of the plant. The high coefficient of the total weight and the weight of the head variables in the first canonical variable suggest that these are the variables that better discriminate and classify the levels of the cultivar factor.

Still in Table 3 canonical coefficients standardized by the total sample and the percentage of the total variability explained by each canonical variable are presented considering the cover factor. In this case, the first canonical variable $(\mathrm{Can} 1=-0.65 P T+1.23 P C+0.56 \mathrm{~V}+$ $0.33 D$ ) or first discriminant function explained $66.03 \%$ of the variation and the second $(\mathrm{Can} 2=-3.66 P T+$ $2.30 P C+0.99 \mathrm{~V}+0.61 D$ ) explained $27.66 \%$. Together, the first and the second canonical discriminant variables explained $93.69 \%$ of the total data variation, summarizing the four initial response variables in only two. For the first canonical variable as well for the second, the variables which received the highest coefficients were total weight and weight of the head. Thus, these two variables were the most important ones in the discrimination and classification of the levels of cover factor.

Figure 1 shows the $95 \%$ confidence ellipses of the mean vectors for levels of the two factors. These ellipses allow good visualization of discrimination between treatments, for each factor. For cultivars (Figure 1a), the ellipses Rubete and Raider Plus overlap, showing that these cultivars do not differ between each other considering the four response variables simultaneously, what had been previously found through multivariate contrasts. These two cultivars showed values of Can1 higher than the cultivar Laurel, that means, showed, in general, weight of the head higher in relation to the total weight. Considering the Can2 variable, higher values are related to the cultivar Raider Plus. Thus, denser and greater volume plants are obtained more frequently in this cultivar than in the other ones. Denser plants are the ones with a greater compactness of the head, which is a commercial advantage.

For the covers, the polyethylene film showed low values for the Can 1 and the Can 2 variables, comparing to the crop covers. Through Figure 1b, it is possible to notice that the confidence ellipse for the cover with polyethylene film is in a range of negative values for both canonical variables. According to the signs of the canonical coefficients (Table 3), that means that the plants for those the polyethylene film was used as cover showed, in general, low weight of the head, volume and density, in relation to the total weight, which is a commercial disadvantage. The sunn hemp cover crop, for example, showed many positive values for Can1. Using this cover crop the plants had weight of the head higher in relation to the total weight, which is a commercial advantage.

These results allowed concluding that the use of polyethylene film as cover did not produce plants commercially competitive. The use of polyethylene film in the cultivation of head lettuce can be replaced by cover crops like the sunn hemp, which results in more competitive plants and promotes environmental conservation.

The multivariate analysis of variance and the canonical discriminant analyses were important in the study of commercial characteristics of the head lettuce. These tools allowed the simultaneous study of the four characteristics evaluated. According to the values of the canonical coefficients 
estimated (Table 3 ), total average weight and average weight of the head were the variables which more discriminated the levels of cultivar and cover factors. The use of these multivariate techniques and others are recommended in horticulture studies.

\section{ACKNOWLEDGEMENTS}

The authors thank CNPq and FAPEMIG for financial support.

\section{REFERENCES}

ANDRADE JÚNIOR VC; YURI JE; NUNES UR; PIMENTA FL; MATOS CSM; FLORIO FCA; MADEIRA DM. 2005. Emprego de tipos de cobertura de canteiro no cultivo da alface. Horticultura Brasileira 23: 899-903.

ARIYO OS; AROGUNDADE O; ABDUL-
RAFIU AM. 2011. Discriminant and classification analysis of health status of bell pepper (Capsicum annuum). Research Journal of Mathematics and Statistics 3: 77-81.

CALEGARI A; MONDARDO A; BULISANI EA; COSTA MBB; MIYASAKA S; ADO TJC. 1993. Adubação verde no sul do Brasil. Rio de Janeiro: AS-PTA. 364p.

CEASA - Centrais de abastecimento. 2012. Catálogo Brasileiro de Hortaliças. Disponível em http://www.ceasa.gov.br. Consultado em 28 março de 2012.

COSTA ARAÚJO R. 1993. Efeitos da cobertura morta sobre a cultura do alho (Allium sativum L.). Ciência e Prática 17: 228-233.

DESUÓ IC; SHIMA SN; OLIVEIRA ACL; GOMES B; DIAS CTS. 2011. Caste asymmetries in the neotropical swarmfounding wasp polybia (Trychothorax ignobilis, Hymenoptera, Vespidae, Epiponini). Sociobiology 57: 51-70.

EFFERSON JN. 1985. Mulch de plastico negro. Agricultura de Las Américas 34: 28-31.

FAVERO C; JUCKSCH I; ALVARENGA RC; COSTALM. 2001. Modificações na população de plantas espontâneas na presença de adubos verdes. Pesquisa Agropecuária Brasileira 36: 1355-1362.

ISIK D; KAYA E; NGOUAJIO M; MENNAN H. 2009. Weed suppression in organic pepper (Capsicum annuum L.) with winter cover crops. Crop Protection 28: 356-363.

JOHNSON RA; WICHERN DW. 2007. Applied Multivariate Statistical Analysis 6. New Jersey: Prentice Hall. 773 p.

KHATOUNIAN CA. 2001. A reconstrução ecológica da agricultura. Botucatu: Agropecuária. $348 \mathrm{p}$.

ROEL AR. 2002. A agricultura orgânica ou ecológica e a sustentabilidade da agricultura, Revista Internacional de Desenvolvimento Local 3: 57-62.

ROSÁRIO MF; SILVA MAN; COELHO AAD; SAVINO VJM; DIAS CTS. 2008. Canonical discriminant analysis applied to broiler chicken performance. Animal 3: 419-424.

SAS Institute Inc. 2008. SAS statistical software: Release 9.2. Cary, NC: SAS Institute Inc.

SAS Institute Inc. 2010. JMP, Version 9.0. Cary, NC: SAS Institute Inc. 